\title{
Persistent Presence of 'Race' in Post-racial 21st Century SA
}

\author{
Jeffrey Sehume \\ Mapungubwe Institute (MISTRA), South Africa \\ *Corresponding Author: jeffreys@mistra.org.za
}

Copyright (C 2014 Horizon Research Publishing All rights reserved.

\begin{abstract}
The paper makes a case for the conclusions that 1 . Race as practice continues to define 'post-race' $21 \mathrm{st}$ South Africa. This is because race acts like an organism more than a system (structures, institutions, constitutions) in being malleable to exploitation based on machinations of political/economic/social power; 2 . The reality of material conditions arguably determines the reconstitutional potential of race and racism; 3 . An inability to address objective conditions has potential to upset projects of social cohesion and nation-building. The conceptual ideas guiding this paper come from Neville Alexander and Ambilavaner Sivanandan in 'Race, Caste and Class in South Africa'.
\end{abstract}

Keywords Race, Feminism, Non-Racialism, Practice, Ethnicity, Community

\section{Race in an International Dimension}

The following is a subjective commentary on political and social matters informing democratic South Africa's positionality in connection with the concept of race and practice of racialisation. It is not intended to be an overview or review of contemporary critical philosophies of race.

This article is not a scientific analysis of the question at hand but provides a socio-cultural perspective on race in South Africa.

When I was writing this paper, three international issues stood on the sidelines to influence my remarks: the Justine Sacco controversy, recent statements by Camille Paglia, and the arrival of the movie 12 Years a Slave (2013).

Concerning the Justine Sacco, you are now familiar with the barebones of this episode. A US business executive books a plane to come to South Africa; en route, she sends a message in her Twitter account. By the time she lands at her destination, the tweet has gone viral and a storm has erupted about the content of that message. Her employers IAC are compelled to fire her for bringing the company into disrepute. What did she say in her tweet? 'Going to Africa. Hope I don't get Aids. Just kidding. I'm white!' An obvious question would be what was she thinking, does she not know that HIV/Aids infects and affects both black and whites, Americans and South Africans? Of course she later recanted her statement after bringing shame to her South African family. The lesson here, as I am sure Professor Anthea Garman would indicate as a media theorist, there is no right to privacy in social media platforms. To say one is writing in their personal capacity is to shirk and avoid the responsibility that comes with communicating in such open spaces.

Regarding Camille Paglia's recent statements, they reflect what she said before. Last year in the December issue of The Wall Street Journal the enfant terrible against mainstream feminism, Professor Paglia said in her 'feminist defense of masculine virtues' - 'The military is out fashion...schools neuter (castrate) male students, opinion makers deny the biological differences between men and women'. These sentiments echo her earlier opinions highlighted twenty years ago in, Sexual Personae, where she declared 'If civilisation had been left in female hands, we would still be living in grass huts'.

Without intending to cause controversy myself, I proceeded to share by e-mail correspondence this article with my female friends (mistake no. 1!), my wife (mistake no. 2!) and male friends. In the main, the response from my male was in some agreement with Prof Paglia and one friend even said he feels so emasculated he does not know when and how to compliment his female colleagues when they are wearing a beautiful outfit. The response from my female friends was something akin to an avalanche of denunciation for sending this sexist article in the first place, apparently endorsing its discriminatory sentiments and for contributing to pushing back the frontiers of gender equity. With regards to my wife's response, let us just simply say a cold war is still brewing in the household.

In connection with the movie 12 Years a Slave, I would state categorically I remain disappointed with the response from some notable critics such as the African-American commentator Armond White who derided this movie as an exercise in 'torture porn'. Most importantly, I am in agreement with the arguments of the director, Steve McQueen. He took to task the Hollywood industry for its 
dismal record in producing movies about slavery which he believes contributes to the collective amnesia perpetrated about this most painful episode in human history. McQueen asked the question why Hollywood has produced hundreds of films on World War II and the Holocaust - events that lasted five years - but has only managed to deliver less than twenty movies on slavery - which lasted for several centuries.

I raise these three issues for the following reasons:

A hundred years ago W.E.B Du Bois professed that the problems of the twentieth century will revolve around race. Has the situation changed? I am not sure if humanity will ever fully overcome the negative effects of race and racism other than transform the systems and structures which enable discrimination and oppression according to race. Perhaps the perseverance of racial thinking will live with us for some time because race can be likened to an organism that forever evolves depending on the motives of the person, groups and institutions using the concept. Therefore, the burdens of racial profiling and general stereotyping remain a site of constant struggle.

This is said for the reason that unless one is convinced humanity will ever reclaim the state of nature spoken of by Rousseau in Discourse on Inequality, where humanity lived in semi-ignorant innocence before birth of civil society and the state, race will insist on being the social category to define the enterprise of western industrial capitalism built on the back of slavery, colonialism and apartheid codified in law in South Africa in 19481.

Secondly, the Paglia responses from my male friends reflect a level of hypocrisy. If we substitute gender for race and said - 'If civilisation had been left in black hands, we would be still living in grass huts' - my male friends and I would the first to raise an alarm. Therefore, transformation does not only concern gender or sexual stereotypes but racial oversimplifications as well. Then again maybe racism is a pandemic like cancer in remaining immovable despite the best knowledge, science and technology at our collective disposal as a human species. It would be thus be recklessly idealistic to characterise South Africa as a successful experiment in social engineering a post-racial society no longer definitively unmarked by assumed biological difference.

\section{Race in South Africa}

In the early to mid-1980s a classic exchange of ideas ensued between two prominent race theorists, the South African Neville Alexander and the Sri-Lankian-born British Ambilavaner Sivanandan.

The following discussion is contextualised by the release

1 A system which benefitted from the theories of Geoff Cronje 'who produced a quartet comprising 'n Tuiste vir die Nageslag (1945) (A home for posterity), Afrika sonder die Asiaat (1946) (Africa without the Asian), Regverdige Rasse-Apartheid (1947) (Just racial apartheid), and Voogdyskap en Apartheid (1948) (Guardianship and apartheid)' (Welsh 2009: 15). last week of the national senior certificate results (grade 12 year-end outcomes) and their relations to economic opportunities.

There can be no doubt that 1994 announced an end to official apartheid policy. 1994 offered an opportunity to think of South Africa to exist beyond exclusively in terms of race. 1994 also enabled the birth of non-racial programmes symbolised by our founding fathers such as Nelson Mandela's in his attempts to forge unity and Desmond Tutu's 'rainbow nation people of God'. 2014 marks twenty years of democracy in South Africa. Much has to be celebrated in terms of political liberation. But the struggle for political liberation has given way to what is called the need for economic emancipation.

What informs this transition from political to economic freedom and how is it related to race matters? The ruling party in government has realised that perhaps both projects of economic and political freedom should have been pursued simultaneously. However, the agreements reached by consensus during the transition from racial oligarchy to a democratic society - the sunset clauses - could not have been avoided.

The transition to demands for economic freedom is related to race in that education is directly linked to economic opportunities. As such race remains a defining marker to understand differences in opportunities. A few statistical facts can helps us. There are more than half a million young people who wrote their 2013 grade 12 examinations. $78 \%$ managed to pass. Unfortunately though, of the 1.2 million people who entered grade 1 twelve year ago, more than 500,000 dropped out for various reasons including financial exclusion and not having access to learning material. In South Africa, we have more than 3 million young people between the ages of 18-24 who are neither in education, employment or training (NEETs).

Furthermore, the 2011 Statistics South Africa (StatsSA) General Household Survey states that ' $44 \%$ of black and coloured youth aged 23-24 had their matric compared with $83 \%$ of Indian youth and $88 \%$ of white youth'. The education researcher Nic Spaull concludes: 'Apart from a small minority, most black children continue to receive an education that condemns them to the underclass of South African society' (2014: 15).In a similar vein, the analyst Jonathan Jansen was indicting: 'If you removed the top 20\% of schools - mainly former white, privileged schools - from the national averages, then a very dark picture emerges of a mainly black and poor school system performing far below the combined results show (of a 78\% national pass rate)' (05 Jan. 2014 Sunday Times)

The above is mentioned focus attention on the persistent presence of race - in education and economic opportunities but to stress the preconditions for building a shared future where race as a social category of analysis may no longer be deemed as all-important. For me, to do otherwise by for example examining race simply on a conceptual is tantamount to navel-gazing which avoids confronting the social ills and political instability which can be caused by an 
army of more than 3 million unemployed, untrained and unskilled young people. The responsibility of ensuring the material prosperity of all citizens irrespective of race, gender, geography is enshrined in the 1996 Constitution. You will recall the words of Thucydides, 'The strong do what they can and the weak suffer what they must'.

I readily admit that the crisis of identity is not necessarily unique to South Africa. As Neville Alexander says: '(what) we are in fact dealing with is a very ordinary country, one which has come very late to the table of the comity of nations' (2002: 1). In attempting to deal with these questions we may be engaged in the rediscovery of ordinary problems that confront all multicultural societies.

\section{Sivanandan-Alexander Debate}

Sivanandan's first proposition: 'you cannot do away with racism by rejecting the concept of race':

South African history is steeped in the politics and economics of race. This has been the case since the initial encounters between the indigenous black populations and traders from the Dutch East Indian Company who were intent on enforcing values of western male Christian civilisation. The trials of the descendants of these traders are captured in J.M. Coetzee's seminal collection of essays, White Writing.

The difference is that race thinking in the apartheid era informed all activities and relations between the diverse social groups. In the democratic era we faced with the conundrum of acknowledging the reality of this race history while at the same time devising means of overcoming race thinking. Is this possible, to seek to transcend definitions responsible for oppression while simultaneously devising new concepts such as non-racialism which are inscribed within this schema of oppression? The academic discipline of anthropology has also experienced something similar to this existential anxiety.

The last time South African history could be said to exist without being bothered with racial categories was more than a thousand years ago at the cross-frontier state-kingdom of Mapungubwe. This civilisation lived in arguably some form of harmony between the inhabitants of what are now South Africa, Mozambique, Botswana and Zimbabwe. This precolonial society was even involved in international trade with Chinese mariners through the town of Sofala in Mozambique. The reason why this history was kept well hidden during the apartheid era was because the very existence of this civilisation upset the narrative of an empty land southern Africa, terra nullius.

In South Africa we seem to attempt to transcend the prison of race, in order to build a non-racial society, by engaging in social activities that allow us to embrace each other across race only momentarily such as was done with the 2005 Rugby World Cup, 2006 Cup of Nations, and the 2010 FIFA World Cup. Are these projects sustainable and do they matter?

Sivanandan's second proposition: 'practice defines terminology, not terminology the practice'.

Precisely because the material conditions defines the operational boundaries of definition, South Africa Incorporated has a difficult battle ahead in ensuring the vision of the National Development Plan (NDP) - our future blueprint for addressing among others poverty, unemployment and inequality by 2030 .

Chapter 15 of the NDP entitled 'Transforming Society and Uniting the Country' envisions making 'it easier for South Africans to interact with each other across racial and class divides', by improving 'the public spaces and public services'.

What does this meant in actual practice? In very elemental terms it speaks to:

1. Instilling in the family unit the values of 'tolerance, diversity, non-racialism, non-sexism and equity'.

2. Fostering in schools a curriculum that helps 'produce inquiring minds - people who are empowered to question and challenge prejudice whenever and wherever they encounter it' plus advancing values of respect for 'social justice, open society, accountability, the rule of law'.

3. Forging linkages between race, non-racialism and media. The NDP blueprint says: "'media industries (and) media culture provides the materials out of which many people construct their sense of class, of ethnicity and race, of nationality, of sexuality, of 'us and the"'. Specifically on the issues of non-racialism, the NDP says 'nation-building' can be sustained through 'campaigns focus(ing) on changing attitudes and behaviour in relation to racist and xenophobic (afrophobic) tendencies. This could include holding dialogues at community (ward) level, where communities discuss their experiences of racism, and how it could be addressed'. For your information, these community dialogues are comparable to the North American experience of 'people's forum'.

4. 'In South Africa, language and race largely go together. The Constitution recognises 11 official languages' but English has assumed a hegemonic dominance in both private and public spaces. 'Knowing each others' languages can play a profound role in promoting understanding and developing social cohesion.

Therefore, these four practical interventions stipulated in the NDP - on the roles of schools, family unit, media and language - also implicates academia in devising conceptual tools, methodological instruments and implementable mechanisms to transcend the centuries-old establishment of scientific or scholarly racialism. What hope is envisaged by Alexander in An Ordinary Country in order to engender an ideal of a unified South Africa nation? 'Ideally every SAn will:

- speak three languages as a matter of course

- have various sub-national (linguistic, regional, 
religious) identities depending on context

- be open to identity extension incl. national and global identifications

- Cherish cultural, biological and political diversity as pillars of a democratic society and survival of the human species' (2002: 109) ${ }^{2}$.

Sivanandan's third proposition: 'you cannot do away with racism by using a different terminology'.

Two incidents underscore the problematics of seeking to overcome racism by using different vocabulary. In his presentation on 'Public Discourse on South Africa's Black Middle Class', Richard Ballard mentioned the ugly regrowth of ethno-nationalist politics in KwaZulu-Natal directed against the Indian business community which seemed to him to be more pronounced than that targeted at the white community. A second incident was witnessed last year when T-shirts written ' $100 \%$ Zulu' ' $100 \%$ Venda' were sold and some motorists had adorned their cars with such stickers. What is striking about such incidence of proto-nationalism is the similarity it shares with thinking of prominent apartheid theorists such as Geoff Cronje who wrote in 1946 the influential paper entitled Afrika sonder die Asiaat (Africa without the Asian).

These incidents of racial and ethnic positivism can be interpreted in several ways. It can be an assertion of on social group's arrival in the post-1994 national politics of a multi-national state paradigm resembling politics of apartheid 'tribal' homelands. It can be reclamation of identities perceived as marginalised during the Mandela and Mbeki presidencies. It can also be read as an indication of the maturity of our democracy where some social groups are not afraid to broadcast their identity. One hopes it is the latter otherwise if would be a revisitation of dangerous essentialism which the former UCT scholar, David Welsh calls the 'politics of ethnic outbidding' (2009: 11) which are responsible for the slaughter of 20,000 townships residents during the so-called black-on-black violence that marked the transition from racial oligarchy to political freedom in 1994.

Similarly, perhaps this is an issue of language and race, as Benedict Anderson asserted in Imagined Community, 'from the start the nation was conceived in language, not in blood' (1983: 133). But why are horizontal interrelationships important in post-apartheid South Africa? The commentator Njabulo Ndebele counsels on the perils of believing in exceptionalism and beliefs in manifest destiny of whatever form. 'The ordinary Afrikaner (and Zulu) family, lost in the illusion of the historic heroism of the group, has to find (in democratic society) its moral identity within a national community in which it is freed from the burden of being special. Afrikaner (and Zulu) culture will triumph from the resultant honesty of self-revelation, the resonances of which will appeal to many others whose humanity has been newly

${ }^{2}$ Echoing these sentiments of 'diversity', Njabulo Ndebele says 'diversity should become a quality-assurance issue at a fundamental level rather than a posture signifying deracialisation. Deracialisation is about more than numbers; it is about bringing to bear new influences on inherited institutional cultures' (2007: 142). revealed by a liberated present' (2007: 89)3.

This paper maintains that indeed - you cannot do away with racism by using a different terminology - but as Neville Alexander says in his publication An Ordinary Country, we can come to terms with the persistent reality of race by choosing "between opting for an ethnically defined, so-called rainbow society in which the primary identity is the "own" ethnic group (however this is described), or we can opt for what I call a Garieb nation - the word "Garieb" is Nama for "Great River" - in which the primary identity is the national, South African identity (2002: 103).

Alexander here stresses the fact that all identities are constructed and contested categories. What gives these identities a bad name, are the operations of power to include and exclude which have accompanied the metarranatives of colonialism, slavery, apartheid, and neoimperialism that has rendered the Middle East and North Africa hotbeds of and for fundamentalist terrorism.

\section{Conclusions}

The road to a post-racial society is long in South Africa given our history and how we have chosen to define ourselves throughout history. Neville Alexander says these epistemological and ontological definitions have ranged from firstly a 'multi-national state' made up of different races in different homelands; thereafter these bantustan states were converted into 'four-nations' categories of African or black, white, coloured and Indian or Asian. Later categories concurrently morphed into 'two-nations' of black and white as President Thabo Mbeki reemphasised in his 1998 speech on the poverty of our national politics whereby one 'nation is white, relatively prosperous, regardless of gender or geographic dispersal. It has access to a developed economic, physical, educational, communication and other infrastructure...The second and larger nation of South Africa is black and poor, with the worst affected being women in the rural areas, the black rural population in general and the disabled' (1998). Finally we have arrived at programmes orientated towards building a South African that is 'one nation'.

\section{REFERENCES}

[1] Alexander, N. An Ordinary Country: Issues in the Transition from Apartheid to Democracy in South Africa. South Africa: University of Natal Press, 2002.

[2] Anderson, B. Imagined Communities: Reflections on the Origin and Spread of Nationalism. London: Verso, 1983.

[3] Gilroy, P. '12 Years a Slave: In our "Post-racial" Age the

${ }^{3}$ Guiding such an ethic of a unified nation, Ndebele recommends a 'move away from parallel development towards horizontal relationships; from security of isolation towards creative risks of interaction; from repression towards expression; from analytical towards integrative modes of thinking...that progress towards relational coherence' (2007: 71) 
Legacy of Slavery Lives on'.TheGuardian, 10 November 2013.

[4] Jansen, J. 'We Need a 50\% Pass Rate', Sunday Times, 05 January 2014.

[5] Mbeki, T. 'Statement at the Opening of the Debate in the National Assembly, on Reconciliation and Nation Building', National Assembly Cape Town, 29 May 1998.

[6] Ndebele, N. Fine Lines from the Box: Further Thoughts about our Country. Houghton: Umuzi, 2007.

[7] Spaull, N. 'Matric is Just the Beginning: But Historical Inequality is Still a Stumbling Block to Success', CityPress, 12 January 2014.

[8] Weiss, B. 'Camille Paglia: A Feminist Defense of Masculine Virtues'. The Wall Street Journal, 28 December 2013.

[9] Welsh, D. The Rise and Fall of Apartheid. Johannesburg: Jonathan Ball Publishers, 2009. 